\title{
The Architectural Aspects of the Traditional Villages in Petra Region With Some Anthropological Notes
}

\author{
Saad Ahmad Twaissi \\ Al-Hussein Bin Talal UniversitylHolder UNESCO Chair for Heritage and Sustainable Development, P.O.Box 20, Maan, Jordan \\ Email: saad.twaissi@ahu.edu.jo \\ Bellal Abuhalaleh
}

Al-Hussein Bin Talal UniversitylDepartment of Archaeology, P.O.Box 20, Maan, Jordan Email: bellal.abuhelaleh@gmail.com

Fawzi Abudanah

Al-Hussein Bin Talal Universityl Director of Center for Nabataean Studies, Al-Hussein Bin Talal Universit, P.O.Box 20, Maan, Jordan Email: fawziabudanh@yahoo.co.uk

Adeeb Al-Salameen

Al-Hussein Bin Talal UniversitylDepartment of Archaeology, P.O.Box 20, Maan, Jordan

Doi:10.5901/mjss.2016.v7n4p

Email: asalamin@hotmail.com

\section{Abstract}

There are many 19th-early 20th centuries villages in the region of Petra, southern Jordan, which are still well persevered but facing a high risk of modern urban expansion. These villages were a subject of full documentation project conducted by the authors in 2011-2013. This paper presents the results of this project in terms of the architectural aspects, including top plan, the general spatial layout of the villages, building technique, building materials, roofing systems, coating materials and other architectural elements. Some anthropological aspects of the inhabitants are also presented. The data collected has many ethno archaeological implications including spatial organization and spatial use, settlement growth and settlement abandonment. Results show that these villages share similar architectural aspects with other rural villages in Jordan in specific and the Levant and Arabia in general. The study has also show that social background of the villagers is well indicated in the spatial organization of the villages. Moreover, results suggest that sedentarized nomadic societies tend to occupy larger space and room areas than rural communities.

Keywords: Architecture, Traditional, Villages, Jordan, Anthropology

\section{Introduction}

There are many late $19^{\text {th }}$ and early $20^{\text {th }}$ centuries villages found all over the region of Petra in the southern part of Jordan. These villages were mostly inhabited till mid 20th century. As a subsequence of modern and urban life, and involvement of the inhabitants in new modes of productions other than agriculture, the villages had been abandoned and its inhabitants have either moved to other Jordanian towns and cities, or built new cement houses nearby. Now most of these villages remain in isolation and still very well preserved. Nevertheless, they are now threatened by the expansion of modern buildings, urbanization activities and increased population growth. On the other hand there is no any attempt to preserve these villages, or at least to document them before they are demolished for modern constructions. The main reason behind this threat is that there is no legal condition provides the preservation of them because, according to Jordanian Law of Antiquities, they are less than 200 years old. Moreover, these villages are private properties, which mean that the owners have the right to do with them whatever they wish. Accordingly, we can understand that these villages are quietly threatened, and it is highly likely to be demolished at any time to use the space for modern activities. For this reason a group of scholars from the local community run a project in 2011-2013 to make full documentation for six villages in Petra region. These Villages are Hai, Emneifah, Baidha, Bani Ata, Rajef and Delaghah (Figure 1). The aim of the project is to get the villages in concern fully documented and to raise a public awareness on the importance and necessity of preserving such a great heritage, and to communicate to the locals the potential of developing these villages 
into tourism product involving local culture. Another objective is to provide students of architecture, anthropology and cultural heritage with new data related to their field of interests. The villages in concern are still well preserved and stand as they were several decades ago, and there is a unique opportunity to have full data on their architectural techniques, spatial organization, land-use and their socio-economic history. Documentation philosophy is to provide detailed database on these villages (geo-referenced maps and plans, photographs and description of architectural techniques and materials, spatial organization, land-use and their socio-economic history) that the villages could be reconstructed again if they face any aspect of damage in the future. The main focus of this paper is to introduce the architectural aspects of these villages with some anthropological notes.

\section{Methodology}

As the main aim of the project is to have a full documentation for the villages, the methodology of documentation includes spotting these villages on digitized aerial photographs and GIS maps as well as sketch maps depicted on topographic maps. Every village was then document as an independent utility in terms of top plan to show house units, gorge etc. Numbering the domestic units of each village in sequence, and every single unit then was documented in terms of walls architecture and construction technique; roofing systems; arches, buttresses etc ; stone types masonry techniques; Other construction materials; coating material and technique; any other features such as niches hearths etc; spatial use and spatial organization inside domestic unites was also described. For the purpose of this project a special description sheet was developed. The sheet contains the illustration of the room or domestic unit in concern depicting its location on the village's plan, its enlarged top plan, 3D representation and representative photos (figure 2). The sheet also contains descriptive information on the unit including room/unit serial number, measurement, wall description, construction technique, construction material, roofing system and material, coating material, flooring and other architectural features (openings, niches etc.). For description purposes walls of each single room were given serial numbers 1-4. Starting with the wall contains the door and was labeled wall no.1, then clockwise the sequencing walls given nos. 2-4 (figure 3).

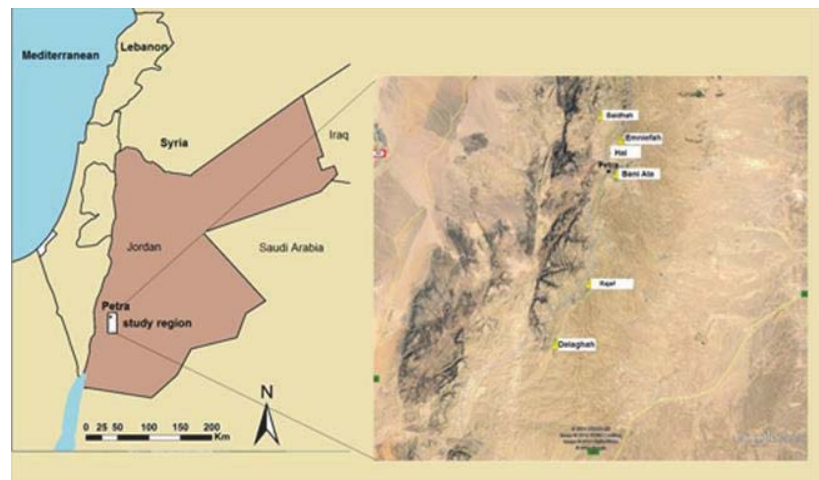

Figure 1: Map shows the study region

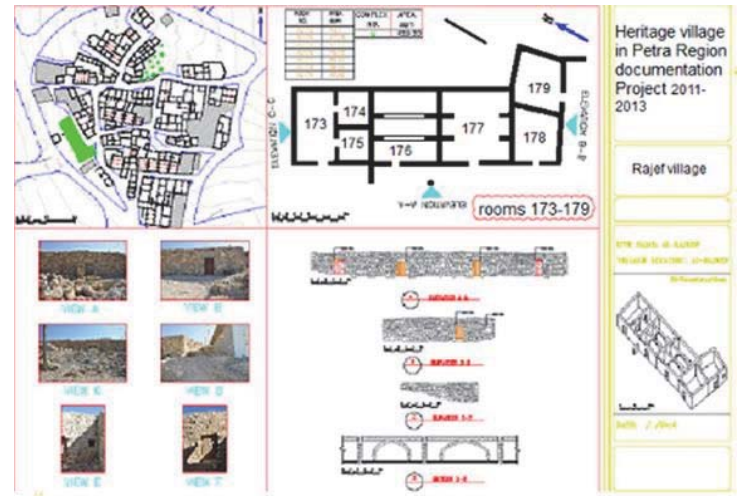

Figure 2: Example for the description sheet developed for documentation 


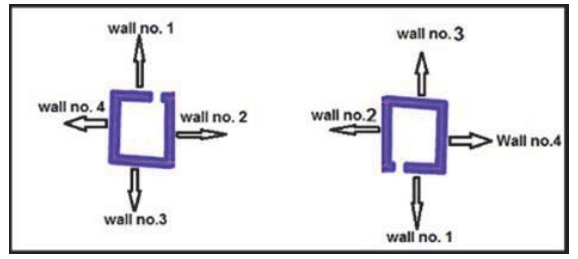

Figure 3: Illustrative example for rooms' wall numbering method

\section{The villages concerned}

At the completion of the project (2011-2013) six villages had been fully documented (figure 4), these are

\subsection{The Al-Hai village}

This village located about $6 \mathrm{~km}$ north of Petra (NE, N 355510.5866;E 360001.5252 and SW, N354834.7695;E359448.5300) and contains 298 domestic unitslroom (figure 5) with a total built area of $8109 \mathrm{~m}^{2}$, distributed in a huge area of about $373720 \mathrm{~m}^{2}$. It was inhabited by a large tribe called 'Ubaidieh, which is a confederation of five sub tribes. Older people of the local community reported that people start to settle their by the end of the $18^{\text {th }}$-early $19^{\text {th }}$ century $A D$, and the village grew gradually in an evolutionary model of settlement growth till the $1950 \mathrm{~s}$. After the 1950s the inhabitant starts to move to Wadi Musa, a modern town on the border of the world heritage site of Petra. The abandoning process was also gradual i.e.

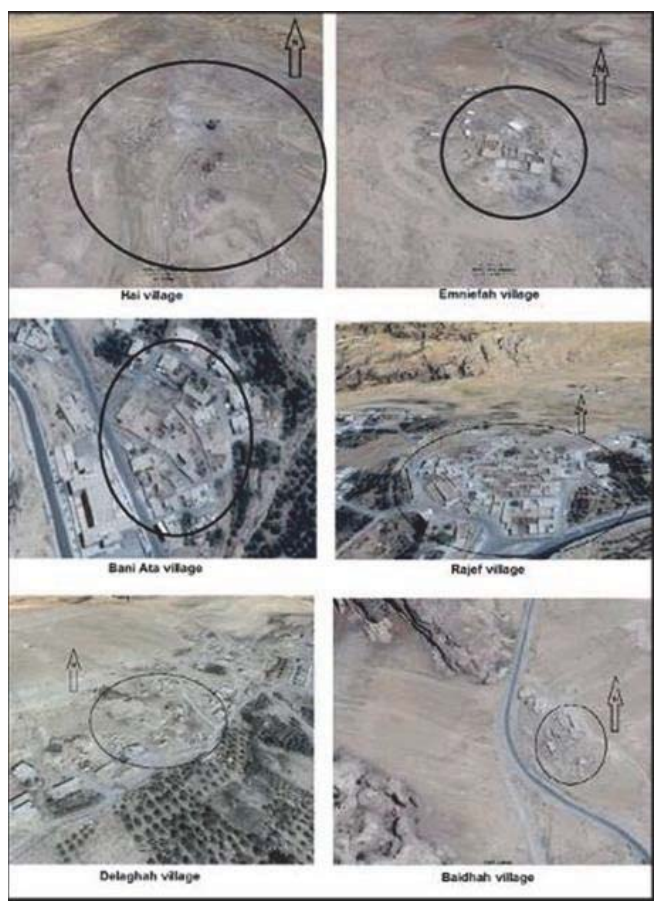

Figure 4: Google Earth images of the villages documented

the last family departed was by the end of 1980s. The subsistence source of the inhabitant was agriculture and livestock raising. They owned the arable lands surrounding the village in which they practiced dry farming of cereals, mainly wheat and barley. Surrounding the arable land zone they pastured their livestock. Al-Hai is the largest village amongst the six villages documented and its domestic units and houses distributed through large area on tribal and family clan basis. The 
general spatial layout of the village is represented by clusters or cells of extended families and clans with narrow gores in between. Within the village there are also public spaces used as threshing floors during harvesting season, as well as animal fences for the livestock. The main water source of the village was the Hai spring which is used for domestic purposes. People used to utilize it by animal skins and jars, and there was no direct connection between the spring and the houses.

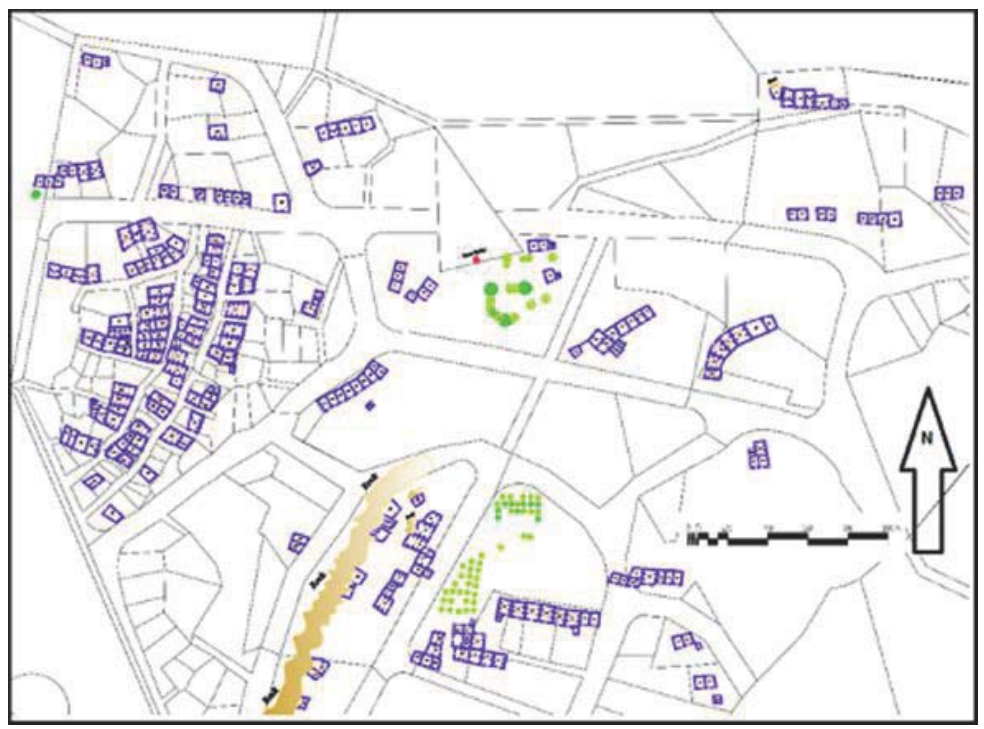

Figure 5: Top plan of Hai village (Drawing: Yehya Hasanat)

A small basin was built on the spring to serve as animal fodder. The spring is also used to irrigate the orchids gardens inside the village. The main orchid grown are olive, pomegranate, apricot, fig and vine. It is worth mentioning that the Hai has long history of occupation and together with several sites in its vicinity was mentioned in the $6^{\text {th }}$ century papyri discovered in the Petra church in 1993 and indicating intensive agricultural activities in this area (Gragos and Frosen1998:474) and this was also evident by archaeological investigation in the region which revealed that the Hai region has continuous human occupation from Iron Age II ( $8^{\text {th }}$ century BC) up to recent time (Lindner 2001, Tholbecq $2001 ; 2013$ ) adding to the fact that most of the masonry stone used in the architecture of the village are reused from the archaeological settlements in that area. Another source for masonry stone is by quarrying the lime stone layers existing there.

\subsection{Emniefah village}

This village located in a close proximity to Al-Hai village (1500m to the west) and was established by a one clan family from the Hasanat sub-tribe who departed at once from Al-Hai to Emnifah in late 1940s. It accommodates 36 domestic units with a total built area of $948 \mathrm{~m}^{2}$ (figure 6). The total space of the village is estimatd at $\mathrm{m}^{2}$ (NE: N354579.2157; E359761.9698 and SW: N354456.3399; E359661.4252). This village was the most compacted one amongst the six villages in the Petra region. This compacted nature can be interpreted in the light of the fact that This could be interpreted on the fact that this village related to one clan family and that it served as one large house for one large family, which was built at once as a large house with preplanned project. The village was abandoned in 1980s. The main water source for the village was the Hai spring, as well as Emneifah well which is of a Nabataean origin (1st century AD). It is clear that that most of the masonry stone used in the architecture are of archeological origin, i.e. they are very well dressed and mostly with medium-large size. 


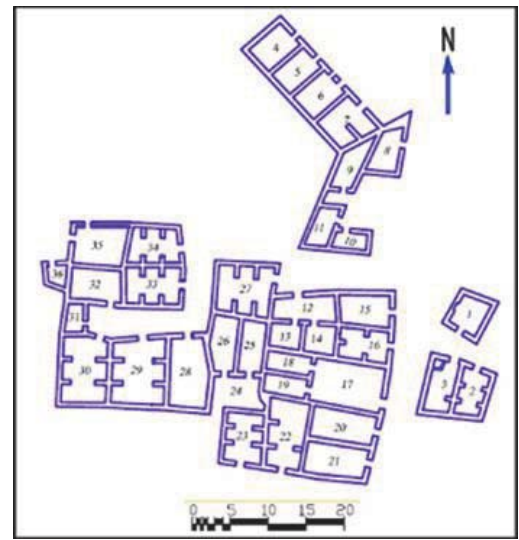

Figure 6: Top plan of Emneifah village (Drawing: Yehya Hasanat)

\subsection{Bani Ata village}

This village is locally known as Khirbit Raidan, named after Raidan spring, and located in Wadi Musa. The existing village is part of a Irager one, i.e about $50 \%$ of the original village was demolished in 1996 for building modern school instead. The demolished part was not documented and irreversibly lost. In fact this incident was one of the main motivation to conduct such a project, supposing that such case will be repeated in the future in other villages. Now, the existing part comprising 88 domestic units with a total built area of about $1750 \mathrm{~m}^{2}$ distributed in an area of about 37000 $\mathrm{m}^{2}$ (NE: N353825.1440 ; E355396.9096 and SW:N353612.1592; E355222.6324). This part is very well preserved and reused now a days by local people as store houses and stockades for their livestock's in winter. The general lay out of this village is compacted and distributed in tribal basis, that each family clan occupy a celllcluster of adjacent houses with narrow gorges in between(see Figure 7). This village is distinguished by having two types of houses: a single room house and a courtyard house (see below). Another note on the architectural of this village is the intensive use of archeological architectural elements. There are abundant ancient friezes, architraves, drums etc reused in the masonry architecture, which means that this village was also built over a previous historical settlement and benefited from the ready-to-use masonry ashlars in the site.

Figure 7: Top plan of Bani Ata village (Drawing: Yehya Hasanat)

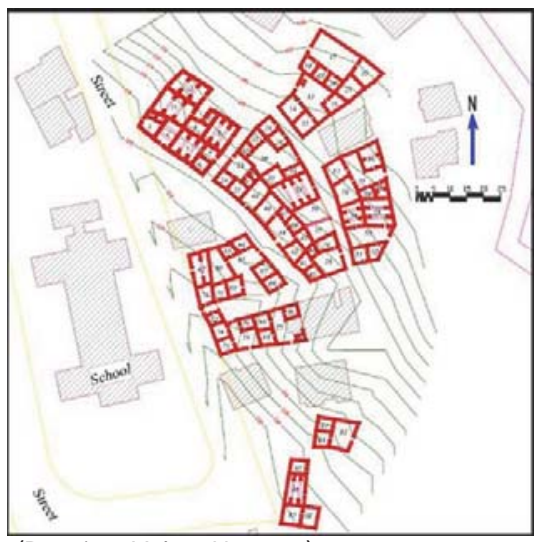

\subsection{Rajef village}

This village located about $18 \mathrm{~km}$ south of Petra and owned by the Rawajih and Sa'iedein tribes, a sedentary nomadic tribe. This village is the second largest one in the region of Petra after Al-Hai village. It is semi-intact and comprises 202 domestic units with a total built area of $7783 \mathrm{~m}^{2}$ (Figur8) occupying an area of $49000 \mathrm{~m}^{2}$. (NE:N350414.1075; 
E342124.1910, and SW: N350168.3558; E341923.1019). According to the oral history of the local people the inhabitants of the village were originally pastoral nomads, and by the 1940s they started inhabiting the village by building a permanent house. Accordingly land division was on tribal basis and then subdivided on hereditary basis. That is, each group of the same genealogical lineage owned one unit of the land in which they established their permanent houses. This case is very much indicated in the spatial layout of the village, i.e very much compacted consisting of clusters of houses related to clan families with small gorges in between. The evolution history of the village is very short, i.e within about 25 years the traditional village was completed. By the late 1970 the new nuclear families of the inhabitant start to build modern cement houses nearby, and now only two families of old people still occupying tow single room houses. The village is not abandoned in a proper meaning of the world, it is heavily used by the locals as store houses for their animal fodders (straw, barely etc.) and as well as stockades for their livestock, because much of the inhabitant still raise animal as their main source of income. For this reason the locals keep maintain it, and it's the best preserved one amongst the Petra region's villages. The main water source of the village is the Rajef spring, and it seems that it is an ancient spring, i.e. the existing cistern in which the spring water collected for redistribution is of a Nabataean origin ( $1^{\text {st }}$ century AD). The village itself is also built over an existing previous historical settlement, mainly Nabataean of first century AD as evident by the abundant pottery on the surface and by the reusing of the typical Nabataean ashlars masonry with 45 angle degree of chisel lines.

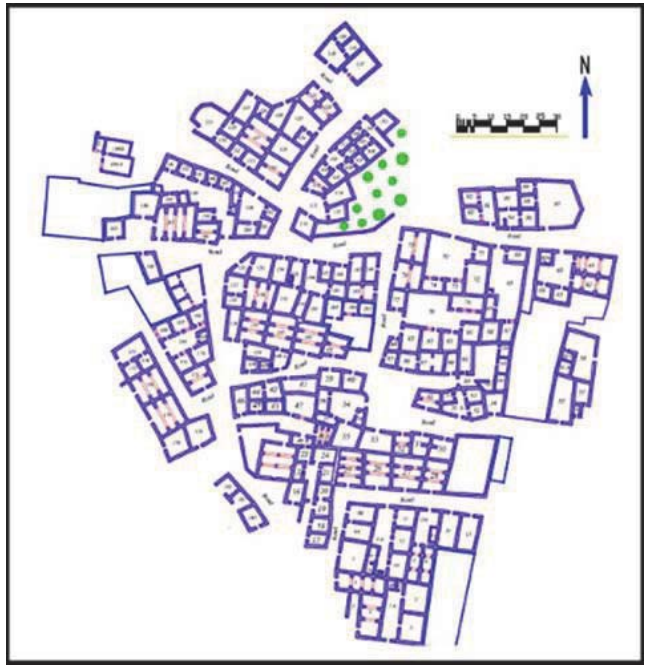

Figure 8: Top plan of Rajef village (Drawing: Yehya Hasanat

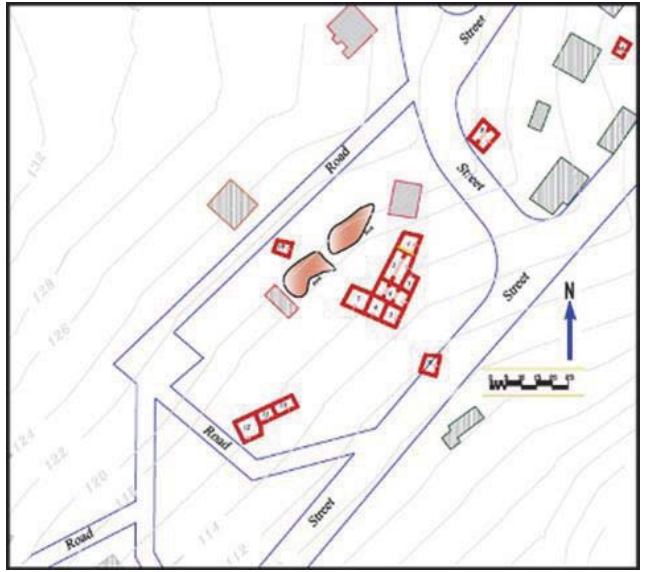

Figure 9: Top plan of Delaghah village (Drawing: Yehya Hasanat) 


\subsection{Delaghah village}

This village is located $40 \mathrm{~km}$ southwest of Petra, and is inhabited by a clan of agro-pastoral nomadic group of the Sa'iedein tribe. It is the smallest amongst the other village documented. The still preserved traditional houses in this village counts 14 domestic units with a total built area of $400 \mathrm{~m}^{2}$ occupying a huge space (NE: N346600.5407; E335478.7615 and SW:N346375.2683; E335294.4298) (Figure 9). Local inhabitants reported to us that there were more traditional houses in the village, but some of them were demolished for constructing modern cement houses. The general lay out of the domestic unit retain the spatial layout of the nomadic tent camp.

\subsection{Baidhah (Amarin) village}

The Amarin village at Baidha is located within the border of Petra Archaeological Park, and was inhabited by a clan of the semi-nomadic Amarin tribe who departed from this village to a newly established one. Their New village was established by the government within the governmental project

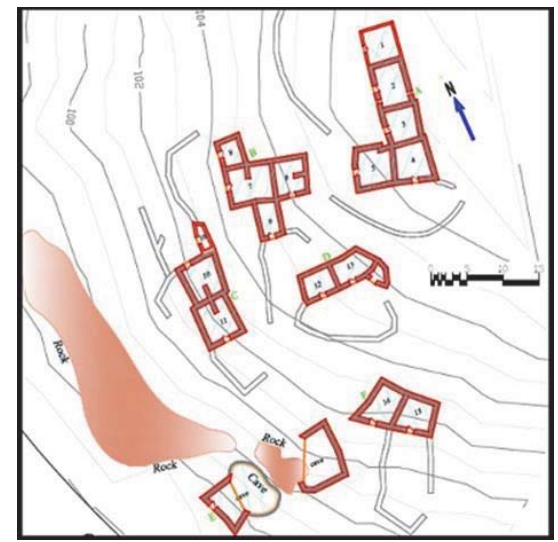

Figure 10: Top plan of Baidhah village (Drawing: Yehya Hasanat

For sedentarizing the nomadic tribes in Jordan. The traditional abandoned village is the second smallest one in Petra region comprising 16 domestic units with a total built area of about $341 \mathrm{~m}^{2}$ distributing in a large area of $8000 \mathrm{~m}^{2}$ (NE: N352070.0745, E363214.5431 and SW: N352070.0745, E363130.7562) (Figure 10). The general spatial lay out of the village is very close to Delaghah village and symbolizing the layout of a nomadic tent camp.

\section{The architectural aspects of the villages}

\subsection{House types}

A total of 654 domestic units were fully documented. Top plan was the fundamental step in the documentation process. Having look at the plans of the villages two main types of houses were envisaged:

\subsubsection{Single-room house}

This type is the most common type of houses in the villages. Basically it is a one space house (figure 11) accommodating a nuclear or extended family and their belonging, and some time their cattle under one roof. This type of house is box-like and always rectangular in shape closed from all sides and only broken by a door in the front facade. It has no windows but small ventilation holes in the upper courses. The inside space could be single when the room is small in area, or it could be divided into one or more subareas by buttresses, arches or small division wall when the room area is very large and accommodate all members of an extended family. Spaces between buttresses or arch shoulders are usually turned into storage installation or silos for crop, mainly wheat by closing it by a thin stone masonry wall coated with thick layer of clay mixed with straw (figure 12). This silos usually has a small hole at 


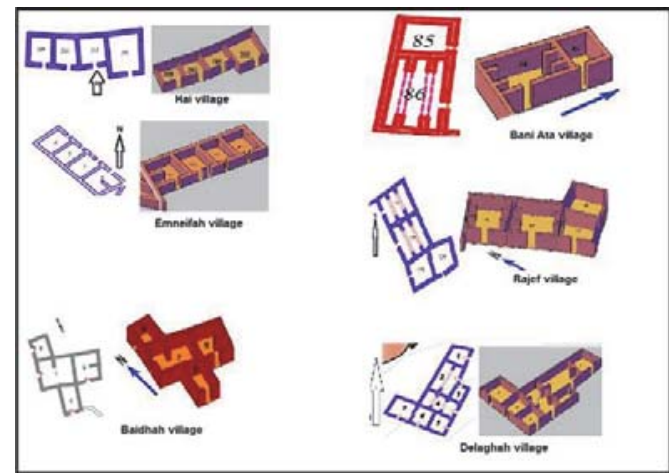

Figure 11: Examples for the single-room house from the villages concerned (Drawing: Belal Abuhelalah)

the base allowing the withdrawal of stored cereals. In few cases this silos may be raised to close up with the ceiling, and hence a filling hole is opened in the roof. In the other side, opposite to the silos, similar space may be turned into warehouse. Extended families of the same clan have their houses of this type built attached to each other in a string of rooms with common activity area in front, "open-air courtyard" (figure 13). This type of houses is the predominant type in rural communities of the Mediterranean and the Near east in general and the Levant in specific (Rjoub and Mahmoud 2012; Mollenhauer 1997; Serghides 2010). In rural Palestine it was classified by Ron Fuchs as a "single-space house' (Fuchs, 1996). Another terminology of this type is "Basic or Closed Rectangular house" (Jager, 2012), and also termed in literature as "simple rectangular room house" (Baglioni, 2015).
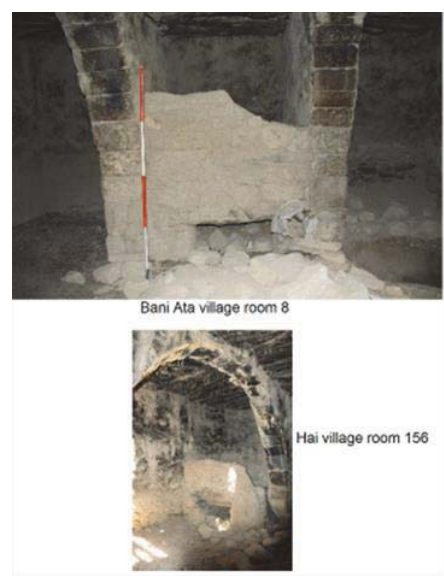

Figure 12: Examples for silos in single-room house in the traditional villages in Petra Region (photo: Sa'ad Twaissi)

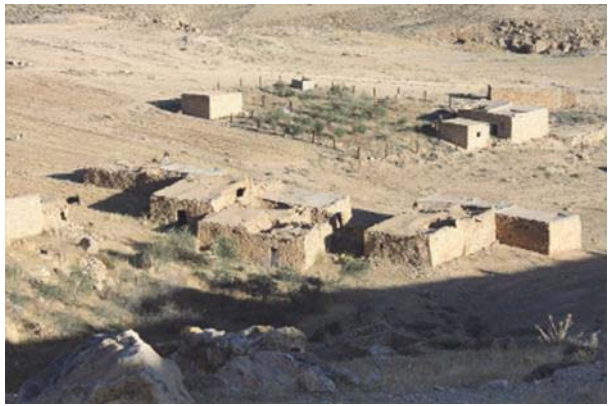

13: Example from Hai village for a cluster of single-room house of a clan of extended families (photo: Sa'ad Twaissi) 


\subsubsection{Courtyard house}

The second type of houses is more complex consisting of one or more rooms with enclosed court yard. In our study we recorded courtyard houses range in size from 2-roomed house up to 5-roomed house (figure 14). In this type each nuclear family of the extended family has its own room, the courtyard however form the public space of the extended family. It is a shared area of the everyday-life activities. In this courtyard there is the cooking hearth area where a shared meal for the extended family prepared. There is also earthen ware oven (tabun), ware house for the collective supply of the family including cereals (wheat, lentil, etc), flour, dried yoghurt (jamid), driedvegetables and fruit (qottaiyen) etc. Dish washing and cloth drying is also conducted in this courtyard. In general courtyard houses are latter in date than the simple house (the single room house) and this, in the case of this region's villages could be interpreted as new sociocultural trends rather than social stratification. In central and northern Jordan, courtyard houses of the early $20^{\text {th }}$ century are more repeated than in the Petra region. However, in central and northern Jordan this type of houses reflecting social stratification and indicating the social statue of the owner (Al-Refai et.al 1988; Faqih, 1988; Amro and Bahauddin 2015; Baglioni 2015) i.e. social organization starts to tend toward privacy and personality of the nuclear family rather than collective life of the extended family (Samadi, 2014). This trend is evident in the very latter houses (after 1950s) where we have

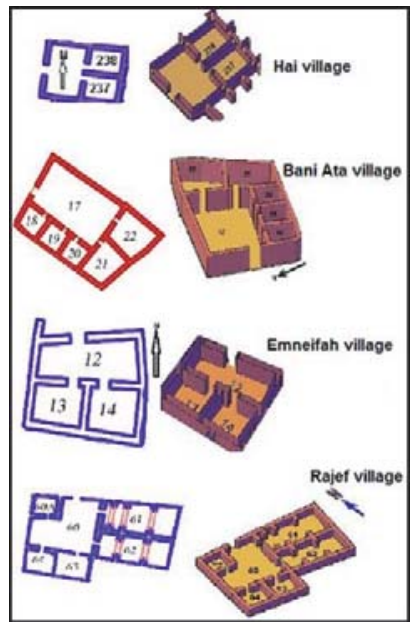

Figure 14: Examples for the courtyard house in the traditional villages in Petra region (Drawing: Belal Abuhelalah)

courtyard houses related to a single nuclear family. Similar socio cultural trend in architecture is reported in many cases from Arab countries and other Middle Eastern Societies (Mughal 2015: 228-229; Ragette 2003). The authors, as member of local communities of Petra region, would also suggest another factor affecting changes in the house types in the region. This is mainly changes in mode of production, i.e. transformation from peasants and agro-pastoral-based societies, to governmental-based recruitment and private tourism investment. This new mode of production is based on individual personal productivity rather than collective productivity of the extended family in rural communities. It should be mentioned here that courtyard house has very long history in the region and considered as a characteristic feature of Islamic architecture in general (El-Shorbagy 2010:16).

\section{Wall construction}

Walls are always built of two rows of dressed and semi-dressed stones forming the interior and exterior faces of the walls. The area in between the rows was filled by mud and ruble stones as well as debetage of the stone dressing in the site. In general building stones are rectangular in shape and they are mostly medium size $(25-40 \times 40-60 \mathrm{~cm})$ (figure 15). At corners walls were interconnected. They are $6-80 \mathrm{~cm}$ in width and the height is $300-350 \mathrm{~cm}$ in average. This construction method is similar to other Jordanian traditional architecture such as that in Iraq Al-Amir (Al-Refai et.al 1988) and Soof village in northern Jordan ( Al-Faqeh, 1989) and other villages (Khammash, 1995). This thick wall is indicating environmental adaptation that it keeps the inside temperature of the space comfortable in summer and winter (Jäger 2012). 


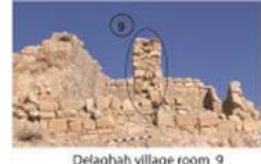

Delaghah village room 9
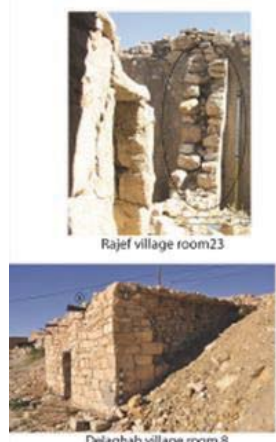

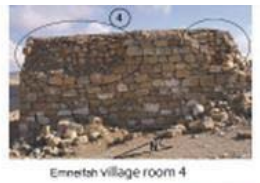

Emeston village room 4

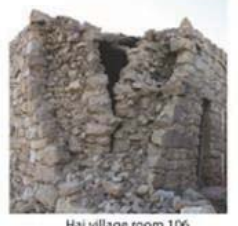

Hai village room 106

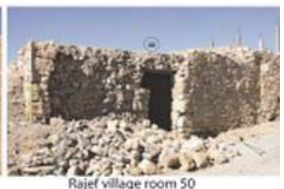

Figure 15: Examples of wall construction technique in the traditional villages in Petra region (photo: Sa'ad Twaissi \& Qais Tweissi)

\section{Mortar}

The main cementing material used in the architecture and construction is local earth. It was used as wedging material between the courses of the walls, and as filling materials between the two rows of the walls (figure 15). Same mud was used in roofing.

\section{Interior coating}

Wall coating is very simple and lacks any aspect of decoration. In all cases of the study area the traditional coating material was made of local dirt mud mixed with straw and applied by hand. A second layer of fine sieved clay mixed with fine straw was applied over the first one (figure 16). The main function of this coating is to protect the bond stone and to save the temperature inside the building, i.e. this coating material has thermal function that it keeps the inside of the space cool in summer and warm in wintertime. In many cases whitewash was applied as a final touch. This coating material and techniques was used widely in the traditional architecture of Jordan and the Levant as whole (Baglioni 2015)
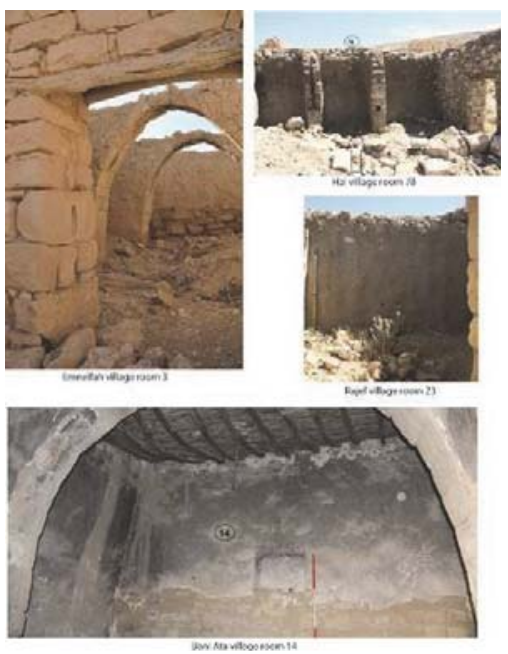

Figure 16: Examples for interior walls coating in the traditional villages in Petra region (photo: Sa'ad Twaissi \& Qais Tweiss 


\section{Floors}

Paved floor are completely absent from these villages, and the only type of floors existed is dirt or compacted mud floor

\section{Roofing Iceiling}

Roofs are always flat, and dome or vault or any other monumental roof are completely absent (figure 17). Roofing material are always the same, it consist of juniper beams span the two sides of the room or the side buttresses or the arches. These beams are laid beside each other with a distance $50-60 \mathrm{~cm}$ apart, and then followed by a layer of juniper branches and Artemisia shrubs. It is worth mentioning here that in local traditions both Artemisia and juniper are used as anti-fungal materials (figure 17). Then a layer of mud mostly clay mixed with straw. The later was beaten several times by stone roll to get well compacted layer. This mud layer may get thicker through time as it needs regular maintenance and addition of fine mud layer annually. In most cases this layer ranges in thickness $30-40 \mathrm{~cm}$.

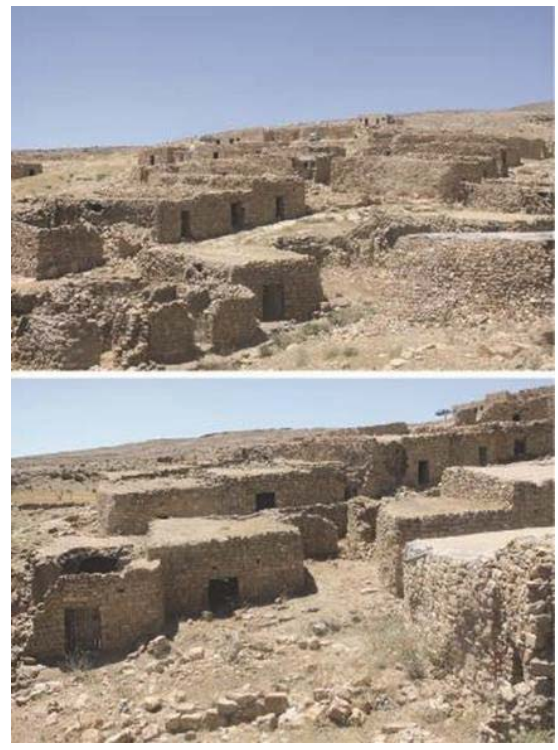

Figure 17: General views of Hai village showing the flat roof and the spatial layout of the village as an example for the traditional villages in Petra region (photo: Sa'ad Twaissi)

The thick ceilings together with thick stone walls introduce the internal space of the roomls with a natural insulation and thermal comfort (Ali et al 2010). In few cases (less than $15 \%$ ) of the documented rooms reed was used as supporting layer above the juniper beams instead of juniper branches and Artemisia shrubs. In this case reed is laid perpendicularly with the beams and set on beside another to form a flat base for the upper ceiling layer (figure 18). Generally reed is also topped by Artemisia or small juniper branches in order to protect the sensitive reed from mice and fungus as well as to work as buffer layer between reed and mud layer of the ceiling. The less usage of reeds is justifiable because of the dry environment of the study region that reed dose not grow in the area and can only be found in seasonal stream valleys. in latter cases juniper beams was substantiated by metal bars stolen from the Hijazi railway which was demolished after World War I.

\section{Roof supporting method}

Flat roofs require supporting. Three construction methods were envisaged in term of roof supporting in the study area. These are: 


\subsection{Side walls}

In this case supporting beams are laid directly on top of the upper course, or on the top of the course before the last one of the interior row of the wall. These beams usually laid horizontally spanning the least width of the rooms (the rooms are mostly rectangular in shape) (figure 19). Usually this method is used when the width of the room is less than $4 \mathrm{~m}$ that a single juniper beam can span the whole width. If the room width exceeds $4 \mathrm{~m}$ then a central beamlbeams is applied to reduce the space and then other beams are laid perpendicularly with the central onels. then the ceiling applied in the same order described above.

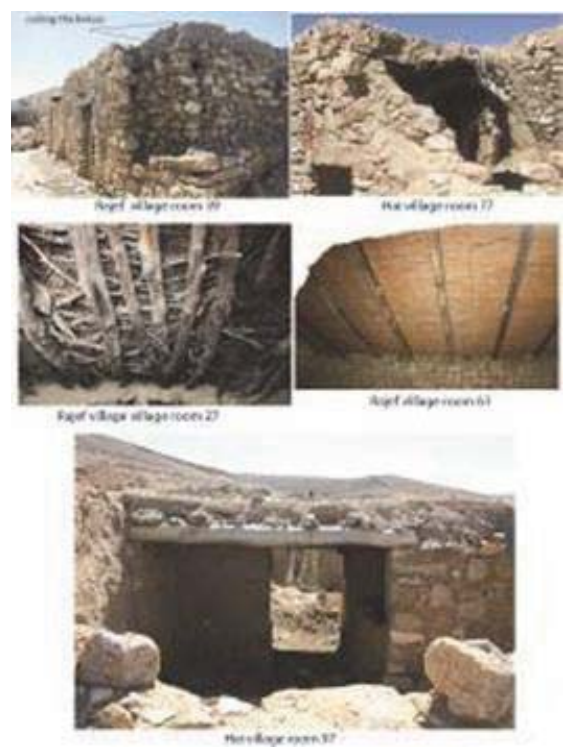

Figure 18: Examples for ceiling materials in the traditional villages in Petra region (photo: Sa'ad Twaissi)
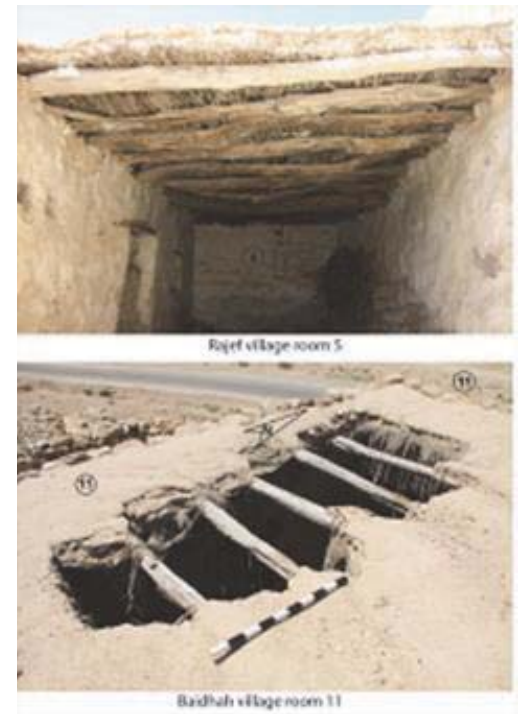

Figure 19: Examples for side walls as roof supporter in the traditional villages in Petra region (photo: Sa'ad Twaissi) 


\subsection{Roofing supported by side buttress}

In all cases side buttresses were used as roof supporter and not as a wall strengthening elements (figure 20). It is usually used when the width of the room is more than $5 \mathrm{~m}$ in order to shorten the space between side walls equal to the length of the juniper beams available. Buttresses might be applied to one side of the wall or may have several buttresses facing each other on both side walls according to the length of the roomlhouse.

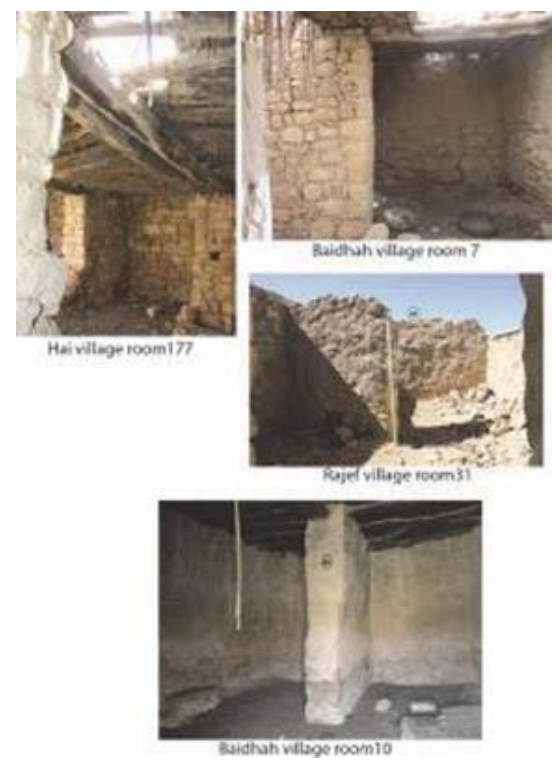

Figure 20: Examples for buttresses as roof supporter in the traditional villages in Petra region (photo: Sa'ad Twaissi

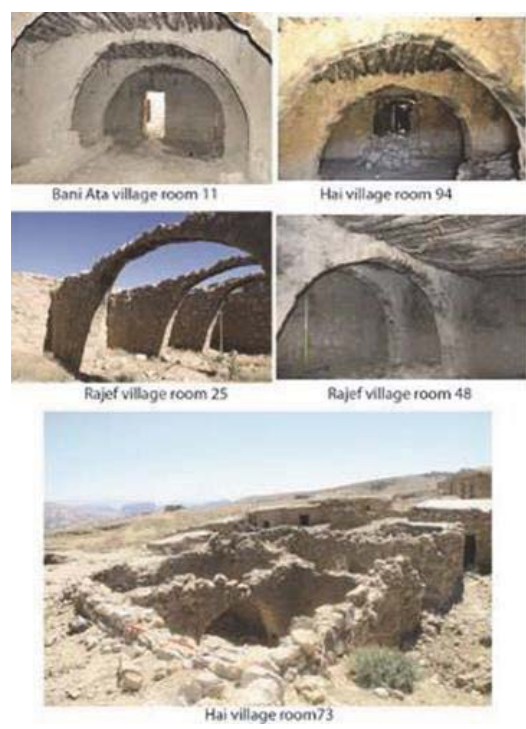

Figure 21: Examples for roof supported by arches in the traditional villages in Petra region (photo: Sa'ad Twaissi). 


\subsection{Roofing supported by arches}

Arches are the dominant roof supporting element in these villages, they are always stand on shoulder walls and also and mostly segmental. Arches springing from the wall are also not existed in these villages. The shoulders of the arch is built with the same technique of the walls (to rows and filling layer in between), and effectively acts as buttresses (figure 21).

\section{The openings}

These include door opening, window opening and ventilation and lightening opening:

\subsection{Door opening}

Door opening are always rectangular $(1: 2)$ and is $(1 \times 2 \mathrm{~m})$ in average. These opening totally lack any aspect of ornamentation, and lintel is always flat from inside and outside formed by small juniper beams embedded between stones. In some cases flat lintel of one piece of stone is placed in the exterior leaf of the double walled masonry. Amongst the recorded rooms only few rooms were with arched lintel (figure 22). In most cases door opening are furnished with stone threshold usually $25 \mathrm{~cm}$ in height, in order to protect the interior from rain water and as protection for the door. Doors are always open inside. The door opening are well framed and accommodate wooden door leaf and door hinge, upper guide track and perforated stone on the ground surface.
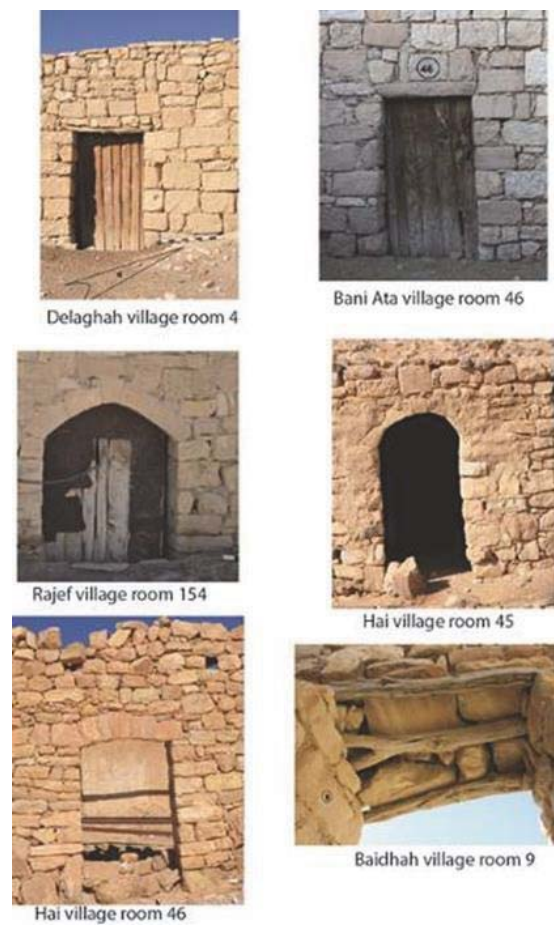

Bani Ata village room 46

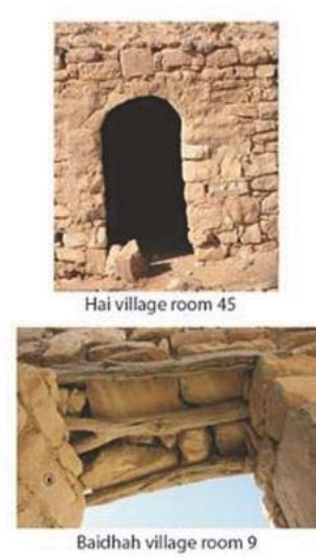

Figure 22: Examples for door opening forms and lentils types in the traditional villages in Petra region (photo: Sa'ad Twaissi \& Qais Tweissi)

\subsection{Windows}

As lower guide track. The door leaf itself is always made of well-shaped and trimmed oak timber beams fitted to a wooden hinge by large iron nails (20-25 cm long). These doors are also furnished with large traditional lock. In general 
earlier domestic units and single room houses are not furnished with windows and have instead small holes in the upper courses of the wallls. only latter houses and mainly the court yard houses have windows opening. As for the windows they are mostly square less than $1 \mathrm{~m}$ each side, and rarely have rectangular ones. When it's rectangular they are always laid vertically. These windows are mostly of flat timber lintels, and rarely found flat stone lintels.

\subsection{Ventilation and lightening}

In the village concerned the main feature of ventilation and lightening, aside of the main door opening, is maintained through small opening (locally called Taqa or Talaqa). They are always placed in the upper courses, above door level and mostly in most upper courses below the ceiling to avoid drafts. In our examples they are mostly found in eastern façade or the western one or in either side, or that to benefit from the sun rise and subset light, and to get better and effective ventilation process as wind in the region is either eastern or western. They are generally rectangular in shape and lay vertically and don not exceeds $30 \mathrm{~cm}$ in length (figure 23). These openings are also serving as smoke outlet mainly in winter time, when heating hearth and cooking took place inside the roomlhouse. In summer time these holes provide a cool breeze through continuous ventilation

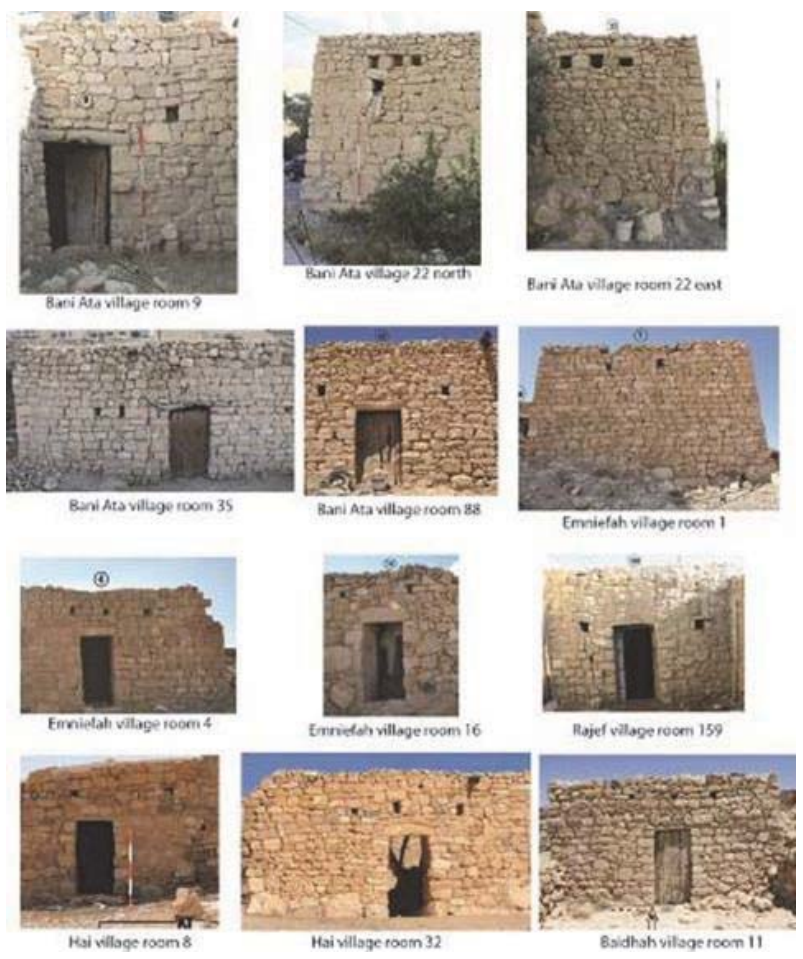

Figure 23: Examples for the forms and distribution pattern of the ventilation holes in the traditional villages in Petra region (photo: Sa'ad Twaissi)

\section{Rain water drainage}

The flat roof is always sloping toward the front of the house directing rain water toward one of the front corners where a gutter placed via which water is dripped into the court yard or the front space of the house. All villages lack any aspect of water harvesting or storage installations. No wells, cisterns or reservoir were documented. This is probably because all the villages have permanent sources of water that there is a spring in each village. 


\section{Discussion and conclusion}

The six villages documented in Petra region shed some light on the architectural traditions of the Petra region communities during the last century (the $20^{\text {th }}$ century). All these villages are completely built out of stone masonry and completely lack the usage of mud bricks, and this may be interpreted in the light of the fact that all these villages were built over archaeological settlement by reusing the building material of the past settlements. Roofing technique is based mainly on juniper wooden bars a fact that may contributed to the degradation of this species in the Petra region during the 20th century. The building materials are totally completely local and lack imported material. The houses are very simple and lack any aspect of ornamentation and architectural decoration. The type of houses presented in these villages is over dominated by the single room/space house, while the courtyard house was not a preferred form for the earlier inhabitants of the villages, and only found amongst the latter built houses (Figures 11-12). From anthropological point of view three of these villages (Al-Hai, Emniefah and Bani Ata) are related to rural agricultural-based communities, while the other three (Rajif, Baidha and Delaghah) are related to sedentarized nomadic communities. However, comparing the spatial lay out and room size of these villages it appears that rural communities tend to occupy larger spaces while sedentarized nomadic societies tend to occupy larger room space i.e. the average room area in the villages of rural communities estimated at $24.47 \mathrm{~m}^{2}$, while the average room area of the sedentarized nomadic societies estimated at $29.46 \mathrm{~m}^{2}$. Further study on this phenomenon may help to get better understanding on archaeo-demography and the relation between settlement size and human population. In general all these villages indicates in its spatial layout the social organization of its inhabitant which based on extended family-clan-tribe, i.e. members of the extended family tend to live together or adjacent to each other (figure 24) and this is a characteristic feature in the spatial layout of the rural villages mainly in Arabia and the Levant (Al-Zahrani et.al 2007). This case is accepted in anthropological logic, that it is known in the anthropology of architecture and human settlement that the general spatial layout of a settlement is affected by sociocultural values and social organization of the inhabitants (Pinxten et.al 1983) In general, the utilization of local material available for the architecture of these villages (earth, stone, wood) indicate the ability of the villagers to adapt to harsh environment of the region such as hot and long dry summer and scarce water resources (Mortada 2003; Fardapour 2013).

\section{Acknowledgment}

The Authors would like to thank the Jordanian Scientific Research Fund for funding this project (Project No. ADMI01103120111)

\section{References}

Ali, H., Zoubi, H. \& Badarneh, S.(2010). Energy efficient design for thermally comforted dwelling units in hot arid zone: case of vernacular buildings in Jordan. in Proceeding of the International Conference on Technology \& Sustainability in the Built Environment, 3-6 January 2010 (pp.279-304). Riyadh, Saudi Arabia: College of Architecture and Planning, King Saud University.

Al-Refai, T. Canaan, R. \& Yaghan, M.(1988). Iraq al-Amir and al-Bardon: the architectural aspects of the Jordanian villages. Amman: The University of Jordan publication. (Arabic).

Al-Zahrani, A. Jbour, S. \& Isa, J.(2007). Ancient architectural pattern at Asir region in Saudi Arabia: its evolution and conservation method, Damascus University Journal for Engineering Science., 23(1), 189-228 (Arabic)

Amro, D. \& Bahauddin, A.(2015). Analysis of the architectural elements in traditional courtyard houses in Irbid, Jordan. Advances in Environmental Biology, 9 (3), 112-116.

Baglioni, I. (2015). Jordanian vernacular architecture. In C.Mileto, F. Vegas, L. Garcia \& V. Cristini, (eds), Vernacular Architecture: Towards a Sustainable Future (pp 105-110). London: Taylor \& Francis GROUP.

El-Shorbagy, A. (2010). Traditional Islamic-Arab house: vocabulary and syntax. International Journal of Civil and Environmental Engineering, 10(4), 15-20

Faqih, S.(1989). Souf: an architectural study in environmental perspective. . Amman: the University of Jordan publication. (Arabic)

Fardapour T. (2013). Analysis of Iraninan traditional architecture through the lens of Keneth Frampton's "Critical Regionalism", American Journal of Engineering and Applied Sciences, 6(2), 205-210.

Fuchs, R. (1996). The Palestinian Arab house: The ottoman connection. Warwick, UK: The University of Warwick

Gragos, T. \& Frosen, J. (1998). Petra Papyri, Annual of the Department of Antiquities of Jordan, 32: 473-481

Jäger, J. (2012). Describing traditional architecture in rural areas, examples from Syria and Jordan. In I.Helmedag \& J. Jäger (eds.), Stone and Architecture in the Mountainous Regions of Jordan and Syria (pp13-60). Amman-Damascus-Berlin.

Kareem, I. (2009). A study on the climatic and social effect of the Arabian courtyard house, Babylon University Journal, 17(1), $446-455$. (Arabic) 
Khammash, A.(1995). Notes on village architecture in Jordan. Arabesue Int.(second edition).

Lindner, M. (2001).From Edomite to late Islamic: settling fluctuation on the newly surveyed Jabal as.Safaha, north of Petra (Jordan), Studies in the History and Archaeology of Jordan, VII,561-568

Mollenhauer, A.(1997). Historical residential houses in as-Salt: remarks on their shape and Function, Annual of the Department of Antiquities of Jordan, 41,415-431.

Mortada, H. (2013). Traditional Islamic Principles of Built Environment. New York USA: Routledge Curzon.

Mughal, M.(2015). Domestic space and socio-spatial relationships in rural Pakistan, South Asia Research, 35( 2), 214-234.

Pinxten, R., Dooren, I. \& Harvey, F. (1983).Anthropology of space: explorations into the natural philosophy and semantics of the Navago. Philadelphia: University of Pennsylvania Press.

Ragette, F. (2003). Traditional domestic architecture of the Arab Region. Stuttgart: Axel Merges.

Rjoub, A. \& Mahmoud, A. (2012). The emergence of agro-pastoral villages in Jordan Hamamet al-Olimat village as a case study, Journal of Human Ecology, 38(3): 231-243.

Samadi, J.(2014). Investigating the courtyards of traditional houses and the effect of Western architecture, Research Journal of Environmental and Earth Sciences, 6(2):112-117.

Serghides, D. (2010). The wisdom of Mediterranean traditional architecture versus contemporary architecture- the energy challenge, The Open Construction and Building Technology Journal, 4, 29-38.

Tholbecq, L. (2001). The Hinterlands of Petra from the Edomite to the Islamic periods: the Jabal ash-Sharah Survey (1996-1997), Studies in the History and Archaeology of Jordan, VII, 399-405.

Tholbecq, L.(2013). The hinterland of Petra (Jordan) and the Jabal Shara During the Nabataean, Roman and Byzantine periods. In M. Mouton \& S. Schmid (eds.) Men in the Rocks: The Formation of the Nabataean Petra(pp295-311). Berlin: GmbH, LogosVerlag.

Twaissi, S. Abuhalaleh, B. Abudanah, F. \& Al-Salameen, A. (2016). The new project on the traditional villages in Petra region with some ethno-archaeological notes. Studies in the History and Archaeology of Jordan, vol. Xii, 739-746. 